\title{
NEW SPECIES FROM THE FAMILY HYDROPTILIDAE IN CROATIAN FAUNA COLLECTED IN THE KRKA NATIONAL PARK WITH PARTICULAR NOTICE TO BIODIVERSITY AND DNA BARCODING
}

\section{Mladen Kučinić ${ }^{*}$, AnĐela Ćukušić ${ }^{2}$, Antun Delić ${ }^{3}$, Martina Podnar ${ }^{4}$, Danijela Gumhalter ${ }^{5}$, Vlatka Mičetić Stanković ${ }^{4}$, Mladen Plantak ${ }^{6}$, Goran Čeple ${ }^{7}$, Hrvoje Plavec $^{8}$ \& Drago Marguš ${ }^{9}$}

\author{
${ }^{1}$ Department of Biology (Laboratory for Entomology), Faculty of Science, University of Zagreb, \\ Rooseveltov trg 6, 10000 Zagreb, Croatia \\ ${ }^{2}$ Croatian Ministry of Potection of Nature an Energetic, Radnička cesta 80/7, 10000 Zagreb, Croatia \\ ${ }^{3}$ Nikole Subića Zrinskog 3, 43290 Grubišno Polje, Croatia \\ ${ }^{4}$ Croatian Natural History Museum, Demetrova 1, 10000 Zagreb, Croatia \\ ${ }^{5}$ Azuritweg 2, 70619 Stuttgart, Germany \\ ${ }^{6}$ Elektroprojekt d.d., Civil and Architectural Engineering Department, Water Resources, \\ Nature and Environmental protection, Alexandera von Humboldta 4, 10000 Zagreb, Croatia \\ ${ }^{7}$ Dintherseweg 14, 5388 VG, Nisteirode, Netherland \\ ${ }^{8}$ Grožnjanska 18, 10000 Zagreb, Croatia \\ ${ }^{9}$ Krka National Park, Trg Ivana Pavla II br. 5, 22000 Šibenik, Croatia
}

Kučinić, M., Ćukušić, A., Delić, A., Podnar, M., Gumhalter, D., Mičetić Stanković, V., Plantak, M., Čeple, G., Plavec, H. \& Marguš, D.: New species from the family Hydroptilidae in Croatian fauna collected in the Krka National Park with particular notice to biodiversity and DNA barcoding. Nat. Croat., Vol. 28, No. 2., 441-454, Zagreb, 2019.

In this study we present: two species of caddisflies new for Croatian fauna from the family Hydroptilidae (Hydroptila simulans Mosley, Orthotrichia costalis Curtis), first DNA barcoding of caddisfly species in the Krka National Park and a discussion about recorded caddisfly fauna in the Krka NP from this study. From a faunistic point of view several species are interesting: Hydropsysche mostarensis Klapálek, Hydroptila simulans Mosely, Hydroptila forfcipata Eaton, Orthotrichia costalis Curtis and Tinodes pallidulus McLachlan. For the species Oecetis notata Rambur we have recorded interesting taxonomical remarks. Furthermore, within this study we used DNA barcoding which showed to be a very good and useful method for identification of very small and morphologically similar species from the family Hydroptilidae, or females from the family Psychomyiidae.

Key words: south Croatia, Dalmatia, the River Krka, Hydroptila simulans, Orthotrichia costalis, Hydroptila forcipata, Hydropsyche mostarensis, Tinodes palidullus, Oecetis notata, molecular analyses COI

Kučinić, M., Ćukušić, A., Delić, A., Podnar, M., Gumhalter, D., Mičetić Stanković, V., Plantak, M., Čeple, G., Plavec, H. \& Marguš, D.: Nove vrste za Hrvatsku iz porodice Hydroptilidae, prikupljene u NP Krka, s posebnim osvrtom na bioraznolikost i DNA barkodiranje. Nat. Croat., Vol. 28, No. 2., 441-454, Zagreb, 2019.

$\mathrm{U}$ ovome radu prikazujemo: dvije nove vrste zabilježene $\mathrm{u}$ fauni Hrvatske iz porodice Hydroptilidae (Hydroptila simulans Mosley, Orthotrichia costalis Curtis), prikaz DNA barkodiranja tulara u Nacionalnom parka Krka te osvrt na faunistički najzanimljivije vrste utvrđene tijekom ovih istraživanja. Faunistički najzanimljiviji su nalazi sljedećih vrsta: Hydropsysche mostarensis Klapálek, Hydroptila simulans Mosely, Hdroptila forfcipata Eaton, Orthotrichia costalis Curtis i Tinodes pallidulus McLachlan. Vrsta Oecetis notata Rambur nazanimljivija je s taksonomskog aspekta. U ovim istraživanjima metoda DNA barkodiranja pokazala se kao vrlo korisna u determinaciji vrlo malih i morfološki sličnih vrsta iz porodice Hydroptilidae te ženki iz porodice Psychomyiidae.

Ključne riječi: južna Hrvatska, Dalmacija, rijeka Krka, Hydroptila simulans, Orthotrichia costalis, Hydroptila forcipata, Hydropsyche mostarensis, Tinodes palidullus, Oecetis notata, molekularne analize COI

\footnotetext{
* corresponding author: kucinic@biol.pmf.hr
} 


\section{INTRODUCTION}

The family Hydroptilidae is the largest family within the order of Trichoptera. The family was established by Stephens (Holzenthal, 2007; Stephens, 1836). The family Hydroptilidae belongs to the suborder Integripalpia and according to Holzenthal et al. (2007) is divided into 2 subfamilies, Hydroptilinae Stephens 1836, and Ptilocolepinae Martynov 1913 (Martynov, 1913; Stephens, 1836). Adult stages are characterized with small body size, the length of some species forewings varies from 1.5 to $2.5 \mathrm{~mm}$ (Hickin, 1967; MALICKY, 2004). However some species from the family Hydroptilidae are bigger and have a forewing length up to 4 or 5 mm (Hickin, 1967; Holzenthal et al., 2007; Malicky, 2004). Since their body size is so small they are called microtrichoptera. Adults of the family Hydroptilidae have very hairy wings (HiскIN, 1967). Members of the family Hydroptilidae are of cosmopolitan distribution, therefore they are found worldwide on all continents (Holzenthal, et al., 2007) except in the Arctic. Currently, there are approximately 2000 species described worldwide (Holzenthal et al., 2007), out of which some hundred occur in Europe (MALICKY, 2004).

The biology of many species from the family Hydroptilidae is insufficiently known, since not all stages of their life cycle are described. According to Oliver Flint "The family Hydroptilidae is the terra incognita of Trichoptera" (FLINT, 1992; Holzenthal et al., 2007). This applies especially to the immature stages of the larvae and the pupae, which are only in some species insufficiently known (НiскIN, 1967). Nonetheless, the features of the majority of the family and the genera are well known, because the life cycle and the morphology of their life stages could be investigated through some well-known species from the genera (Hickin, 1967; MARShall, 1978). After copulation the female flies close to the water and lays the eggs attaching them below the water surface on rocks or submerged vegetation (MARshall, 1978). One of the main features of the family Hydroptilidae is that the first four instar stages of the larva last very short, they do not build cases and the morphology resembles those of some plankton crustaceans. Only the fifth instar builds cases out of sand and tiny stones. The cases are of a very specific and characteristic shape, the one of a bottle (HICKIN, 1967; WARINGER \& GRAF, 2011). Such a life cycle is called hypometamorphosis and is known only in this family of Trichoptera (MARSHALL, 1978).

Larvae feed on detritus or macrophytes, including filamentous green algae (MARshall, 1978). These feeding habits are expressed especially within the fifth larval stage of development when larvae are preparing to undergo to adult stage development. Many species have one or two generations in Europe, while a number of generations can be higher in subtropical and tropical area.

The family Hydroptilidae comprises many various genera that inhabit quite diverse habitats, from springs and mountain creeks, all the way to large rivers and rather less in lakes as well as in habitats made by men, e.g. canals ( $\mathrm{O}^{\prime} \mathrm{CoNNOR}$, 2015). Adult forms tend to inhabit areas close to the aquatic habitats of larvae, like surrounding rocks, banks and bank vegetation (MARshaLL, 1978). 
DNA barcoding is the newest identification method (HeBERT et al., 2003a, b) that has significantly contributed (with other molecular analyses) to the knowledge of the diversity, taxonomy and discovery of cryptic species (for example BILANDžIJA et al., 2013; Brenm et al., 2019; CÁrdenasi et al., 2013; Elías-Gutiérrez et al., 2008; Guo et al., 2016; Previšić et al., 2014; Sмit et al., 2016; Tyagi et al., 2017; Vaglia et al., 2008; ViтECEK et al., 2015), improvement of identification of species that are difficult to identify by morphological features, to biomonitoring, phylogenetic and phylogeography (for example Brenm et al., 2019; KANG et al., 2017; SANTOS et al., 2016; VIтесек et al., 2017). It is as almost no other method since the time of Linneaus (LinNAEUs, 1758) has made such great influence in zoology like DNA barcoding. First papers on DNA barcoding and the BOLD System database (RAtnasingham \& Hebert, 2007) published in Croatia are only several years old. Nonetheless, application of the method is intensive and has a growing trajectory in Croatia, as well as in the rest of Europe and the World.

The objectives of the present study were: 1.) to present two new records of caddisfly species in Croatia; 2.) to provide first DNA barcoding of caddisfly species in the Krka NP; 3.) to discuss recorded caddisfly fauna in the Krka National Park with previous studies. The results of this study are part of the project "DNA barcoding of biodiversity of Croatian fauna".

\section{MATERIAL AND METHODS}

\section{Field work}

Field investigations in the Krka National Park (Krka NP) (south Croatia, region Dalmatia) were conducted from 2017 until 2019 (leg. A. Delić, H. Plavec, G. Čeple, M. Kučinić). The material was collected on several localities in the NP.

However, the DNA barcoding method was used on specimens collected only on the following four localities (Figs 1, 2 A-D): Brljan Lake (Fig. 2A), hydroelectric power plant Miljacka (HPP Miljacka) (Fig. 2B), waterfall Roški slap (Fig. 2C) and Lake Visovac (a dock near the island Visovac) (Fig. 2D). The first locality is located at the very end of the Brljan Lake (Fig. 2A), behind the dam on the bridge, close to the left side of the River Krka. The locality is situated on a paved road, which leads over the bridge. On both sides, it is predominantly covered by forest vegetation, including some fig trees and cherry trees. The locality hydroelectric power plant Miljacka is located inside the hydroelectric power plant close to the Brljan Lake (Fig. 1), on the upper course of the River Krka. The aquatic insects were collected on the left side of the river, next to the main building of the hydroelectric power plant. The River Krka forms at this place canyons and the water current is rather strong with expressed saturation (Fig. 2B). Mosses cover flagstones and the river resembles at this place an upper stream of a mountain river. Hydrological specifications of this part of the River Krka are underground springs on the right side of the river, which connect the River Krka and river Zrmanja (BonAcCi \& Roje-Bonacci, 2015). The waterfall Roški slap is one of the most recognizable part of the River Krka. Characteristic are tufa and a cascade of smaller waterfalls which contribute to a stronger saturation (Fig. 2C). In this part the River Krka is wide, 
with a lot of bushy and forest vegetation on its riverbanks. Material was collected on the bridge, close to the right side of the River Krka. Aquatic insects, including Trichoptera, were collected approximately 50 meters away from the right side of the river. The last locality, Visovac Lake is located on the lower section of the River Krka (Fig. 1), near the island Visovac. It is situated on a small boat dock on the right side of river Krka. The river is in this place very wide and resembles a lake. Therefore, this part is called Visovac Lake (Fig. 2D). The riverbanks are covered by marsh vegetation of reed and water plants.

\section{Laboratory work}

In order to use DNA based method of specimen identification along with morphological features all collected material was preserved with absolute ethanol. The DNA vouchers of the barcoded samples were stored in the Croatian Natural History Museum in Zagreb and in the Trichoptera collection "Kučinić".

Macrophotographing of Trichoptera adults was carried out using a Leica Wild MZ8 stereomicroscope and Olympus SP-500 UZ digital camera, processed with computer program Olympus Quick Photo Camera 2.2 at the Laboratory for patology of trees, Department of Forest Protection and Wildlife Management at the Faculty of Forestry, University of Zagreb.

Determination of species was done according to MaLicky (2004) and Kumanski (1985, 1988). Systematic followed Morse (2019).

\section{DNA extraction and PCR amplification}

Genomic DNA was extracted from legs of 21 specimens listed in Tab. 1 with specimen ID marked with bold letters. In Tab. 1. there are data of determination according to morphological features (first column), specimens ID, Locality/ Family, BOLD Sequence ID and species identification (\%) after DNA barcoding analyses (last column).

Genomic DNA was extracted using GenElute Mammalian Genomic DNA Miniprep kit (Sigma-Aldrich, Germany) according to the manufacturer's specifications and eluted in $50 \mu \mathrm{l}$ of elution buffer. For the amplification of the COI-5P barcode region primers: LCO1490 and HCO2198 (C 1994) ware used. The volume of mixture for polymerase chain reactions (PCR) was $50 \mu \mathrm{l}$. The PCR mixture contained $1 \times$ Go Taq®Reaction Buffer (containing $1.5 \mathrm{mM}$ $\mathrm{MgCl} 2$, Promega), $0.2 \mathrm{mM}$ of each dNTP, $0.4 \mu \mathrm{M}$ of each primer, 1.25 units of Go Taq ${ }^{\circledR D N A}$ Polymerase (Promega) and $5 \mu$ of DNA eluate. PCR cycling conditions comprised an initial denaturation step $\left(94^{\circ} \mathrm{C}\right.$ for $\left.2 \mathrm{~min}\right)$ followed by 35 cycles of denaturation at $94^{\circ} \mathrm{C}$ for $30 \mathrm{~s}$, annealing at $50^{\circ} \mathrm{C}$ for $30 \mathrm{~s}$ and elongation at $72^{\circ} \mathrm{C}$ for $90 \mathrm{~s}$ and a final extension step of $72^{\circ} \mathrm{C}$ for $7 \mathrm{~min}$. Product purification and bidirectional sequencing was performed by Macrogen Inc. sequencing service (Seoul, South Korea) and Macrogen Europe (Amsterdam, the Netherlands) using the amplification primers. Sequences were edited manually and aligned using the program BioEdit (HALL, 1999). 
DNA sequences obtained in this study were submitted to Barcode of Life Data Systems (BOLD, Ratnasingham \& Hebert 2007, Tab. 1). For 21 DNA barcode sequences obtained in this study, similarity search was performed using the BOLD Identification Engine (available on http://boldsystems.org/) which uses

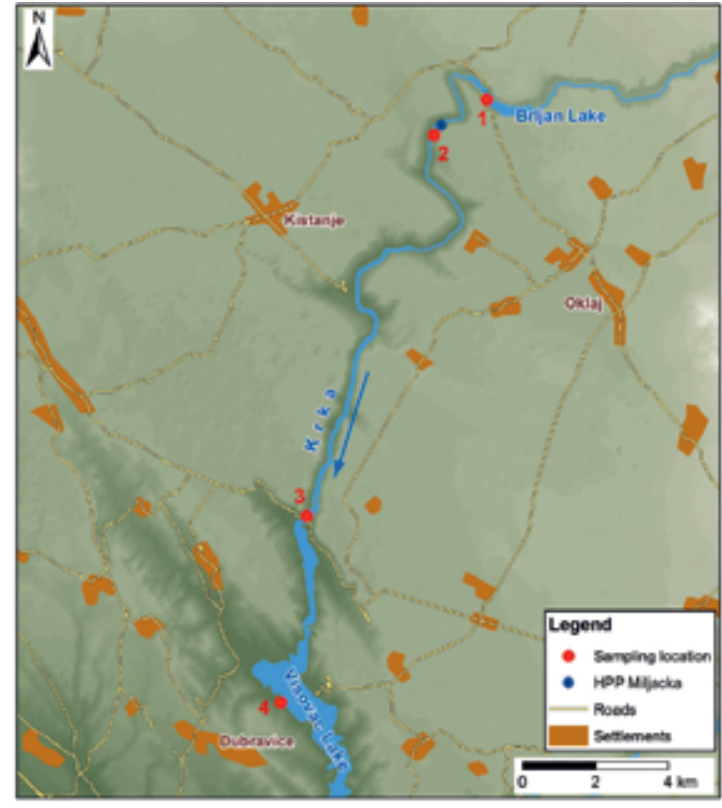

Fig. 1. Simpling sites in the Krka NP: 1 - Brljan Lake, 2 - HPP Miljacka, 3 Roški slap, 4 - Visovac Lake.
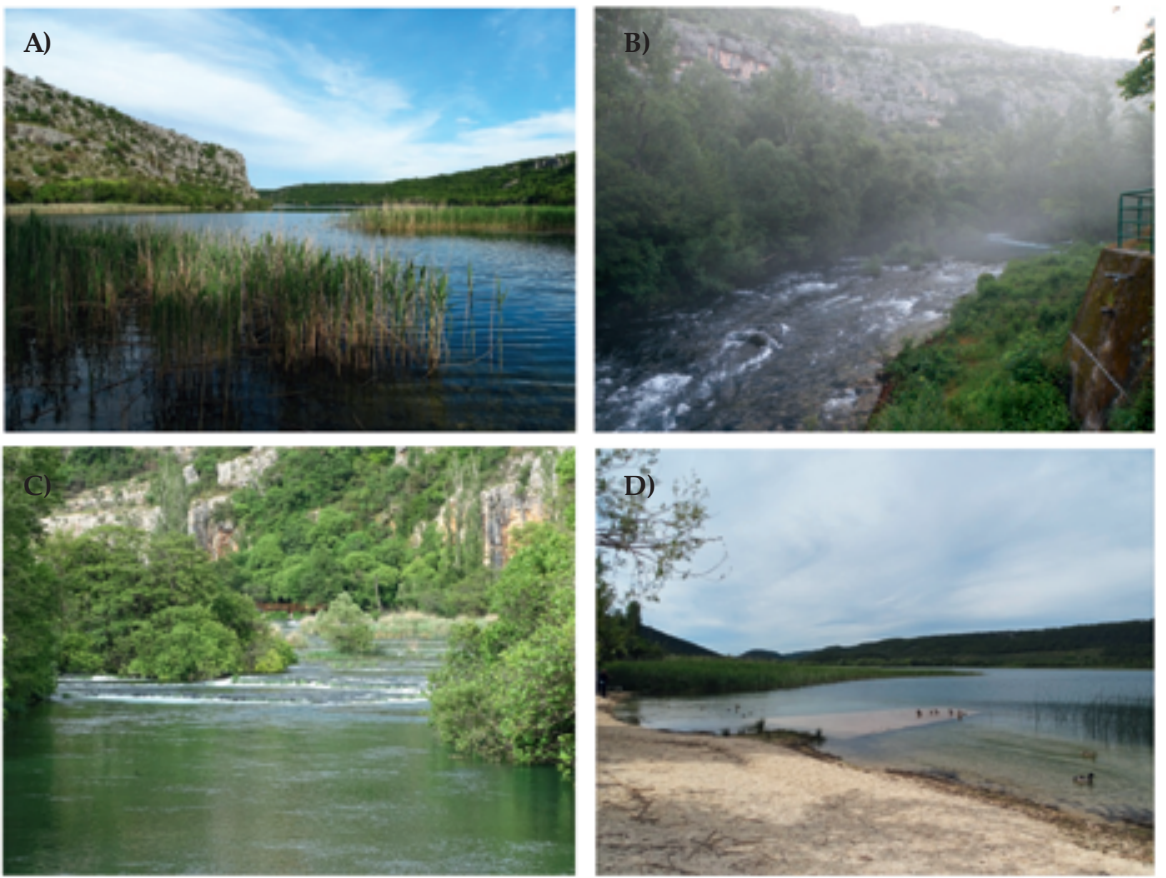

Fig. 2 A-D. Photographs of the sampling sites in the Krka NP: Brljan Lake (A), HPP Miljacka (B), Roški slap (C) and Visovac Lake (D) (photo A. Delić). 
all sequences uploaded to BOLD from public and private projects to locate the closest match.

\section{RESULTS AND DISCUSSION}

Throughout recent investigation on Trichoptera of Krka NP (Kučinić et al., 2011; RidL et al., 2015), conducted between 2017 and 2019, some interesting faunistic findings have been recorded and confirmed by using DNA barcoding method (Tab. 1). Altogether 21 Trichoptera specimens have been DNA barcoded. The specimens belong to 8 families, 11 genera and 16 different species (Tab. 1), which makes approximately $30 \%$ of all established Trichoptera fauna in the Krka NP (Kučinić et al., 2011; RidL et al., 2015).

From a faunistic point of view several species are very interesting: Hydroptila simulans Mosely, 1920, Orthotrichia costalis (Curtis, 1834), Hydroptila forfcipata Eaton, 1873, Hydropsysche mostarensis Klapálek, 1898 and Tinodes pallidulus McLachlan, 1878. The species Oecetis notata (Rambur, 1842) (Tab. 1) is interesting from a taxonomical point of view.

Only one species from the family Hydroptilidae has been previously known from Krka NP: Hydroptila sparsa Curtis, 1834 (Kučınıć et al., 2011; Ridu et al., 2015). This species has also been reconfirmed during this investigation. Another three new species have been discovered in Krka NP: Hydroptila simulans, H. forfcipata and Orthotrichia costalis. The findings of the species $H$. simulans and O. costalis are the first findings of these species in Croatia. Determination of all three species has been undertaken by applying DNA barcoding, and their COI sequence has been entered in the BOLD System Database (Tab. 1). Since the family Hydroptilidae has adults of very small dimensions, DNA-barcoding has proven to be a very important tool for accurate determination of species (Tab. 1). This example, as well as the whole family Hydroptilidae, shows the importance of DNA barcoding,
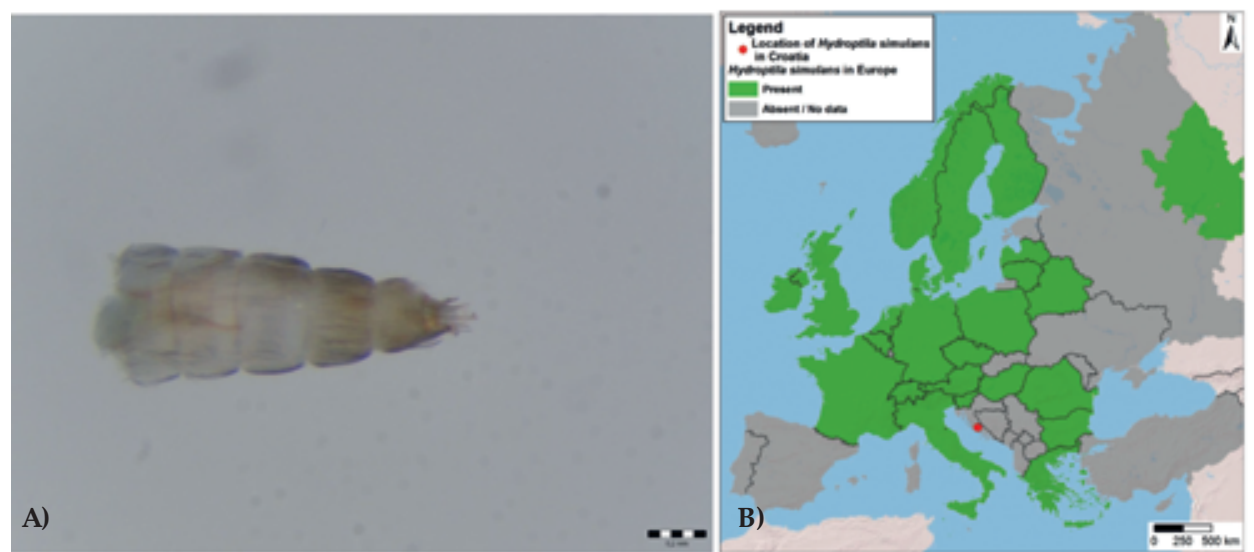

Fig. 3A-B. Abdomen and genitalia of Hydroptila simulans Mosely, 1920 (A), ventral view (photo M. Kučinić). Distribution in Europe according to Fauna Europaea (B). Red circle: record in the Krka NP. 
which serves as an addition to taxonomical, phylogenetic and phylogeographical investigation, as well as investigation of different aspects of biomonitoring, conservation biology and protection of specific species and their habitats.

Hydroptila simulans (Fig. 3A) is widely distributed species in Europe, from Scandinavia, Ireland (O'CONNOR 2015) and Great Britain (Hickin, 1967; BARNARD \& Ross, 2012) in the north all the way to Greece in the south (MaLicky, 2005) (Fig. 3B). The forewing length is $3 \mathrm{~mm}$ (МацiскY, 2004). The fifth larval stage of this species builds cases from surrounding mud (O'ConNor, 2015). Adults are active from May to August ( $\mathrm{O}^{\prime}$ ConNor, 2015) which is consistent with our study and data from Krka NP. In the National Park we found this species in August 5, 2019. So far, H. simulans was recorded in the lower part of the Krka River at the locality in Visovac Lake (Fig. 2D). That is the only record of the species in Croatia so far.

Orthotrichia costalis is one of five European species of the genus Orthotrichia (MALICKY, 2004). They are small sized caddisflies with the length of their forewings of only $3 \mathrm{~mm}$ (MaLicky, 2004). They mainly inhabit slow running waterbodies such as large rivers, lakes or fishponds ( $\left.\mathrm{O}^{\prime} \mathrm{CONNOR}, 2015\right)$. So far, this species was recorded only at two localities in Croatia, both in Krka NP: Roški slap (Fig. 2C) and Visovac Lake (Fig. 2D). At the locality near the island of Visovac Krka River reaches its widest shape with a very slow current which hydrologically resembles a large lake. On the contrary, locality Roški slap has different hydrological characteristics, but the Krka River is very wide there with areas where very slow current occurs. In the contrast to majority of European species of family Hydroptilidae, larval stages of $O$. costalis are well known (O'ConNor, 2015; WARINGER \& GRAF, 2011). Larvae build protective cases from silk threads, which are rounded, elongated and narrowed in front and hind end, but not pointed (WARINGer \& Graf, 2011). The species O. costalis is widely distributed species in Europe, from Scandinavia and Great Britain in the north to Greece in the south

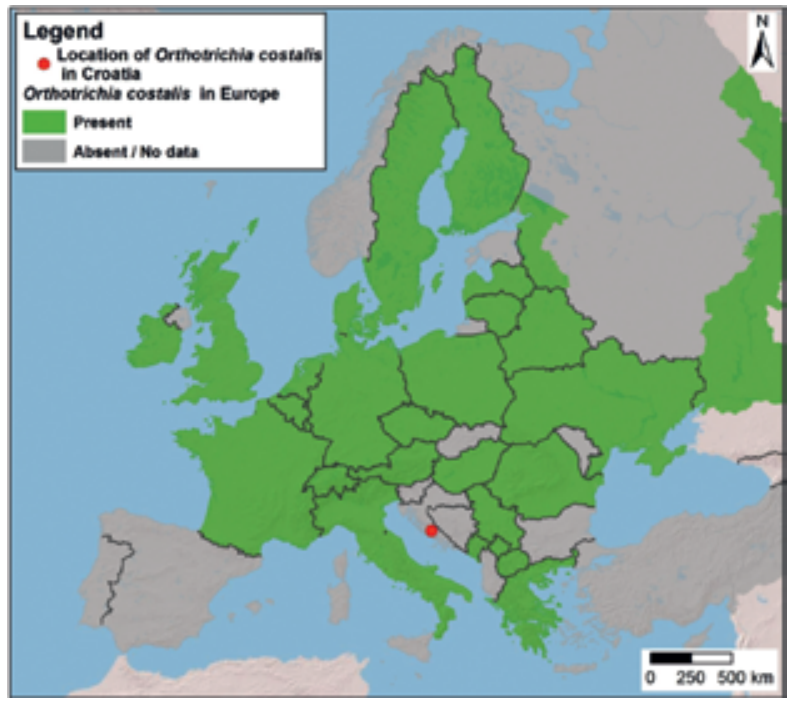

Fig. 4. Distribution of Orthrotrichia costalis (Curtis, 1834) in Europe according to Fauna Europaea. Red circle: records in the Krka NP. 
(Malicky, 2005). The species is absent from Iberian Peninsula, Corsica, Sardinia, Sicily and Malta (Fauna Europaea) (Fig. 4). DNA barcoding showed to be a very good and useful method in identification of O. costalis (Tab. 1).

Hydroptila forcipata (Fig. 5, Tab. 1) is the third newly recorded species from the family Hydroptilidae in Krka NP. With three new records presented in this article, and previous two records of Hydroptila sparsa and Allotrichia pallicornis Eaton (1873) (Kučinıć et al., 2011; RidL et al., 2015), in Krka NP altogether 5 species of Hydroptilidae have been found so far. It is the first finding of H. forcipata in the Mediterranean part of Croatia. Adults appear in Greece from April to October, and in central Europe from May to October (МАцiскY, 2005). In the Krka National Park we found this species in September. The species $H$. forcipata is widespread in Europe except Iceland in the north, and Portugal, Corsica, Sardinia and Malta in the south (Fauna Europaea, 2019; Hickin, 1967; Ibrahimi et al., 2012; Malicky, 2005).

During this study the species Hydropsyche mostarensis is reconfirmed for the area

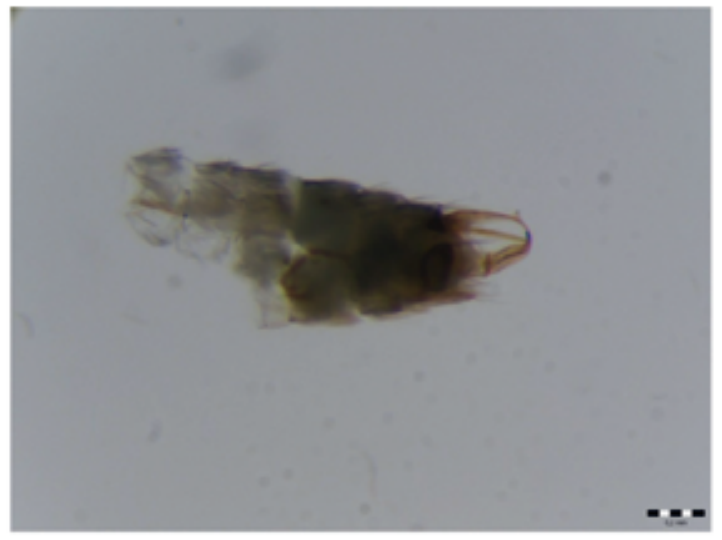

Fig. 5. Abdomen and genitalia of Hydroptila forcipata Eaton, 1873, lateral view (photo M. Kučinić).

of the NP Krka in the same locality, HPP Miljacka (Kučınıć et al., 2011) (Fig. 2B). Only one specimen was collected on August 5, 2018. DNA-barcoding was applied to this specimen and the results entered in the BOLD platform. This represents the second record of H. mostarensis in the Barcode of Life Data System (BOLD). This finding from the Krka NP is very interesting for the Croatian Trichoptera fauna, since it represents the only site for Croatia (Kučinić et al., 2011). Krka NP is the westernmost point of the species distribution, which biogeographically belongs to southern European species (Fig. 6). The closest finding originates from the spring of river Lištica in Bosnia and Herzegovina (Stanić-Koštroman et al., 2012, 2015). The larva of H. mostarensis has been described from Greece (Karaouzas, 2018) and is different from well described larvae of the genus Hydropsyche from this area. This species belongs to Hydropsyche gutata Group (Karaouzas, 2018). Hydropsyche mostarensis prefers spring areas (StANić-Koštroman et al., 2012) and prefers lower habitat temperatures (KARAOUZAS, 2018). In this specific case the side springs of river Krka, close to the HPP Miljacka, cause low temperatures from 10.5 up to $15.2{ }^{\circ} \mathrm{C}$ with a very low maximum water during summer (Kučınić et al., 2011). This probably suits the species $H$. mostarensis. Since this is the only finding of 
this species from Croatia special attention should be paid to its conservation. In fact, the species has never been before or after collected on any of approximately 200 other Trichoptera sampling sites, which have been visited during the last 20 years. Although this area is protected as a national park, negative effects are possible since this is also the location of the hydroelectric power plant. Until now, no negative effects could be traced. Therefore it is suggested to continue with the same management of the hydroelectric power plant and the nearby area.

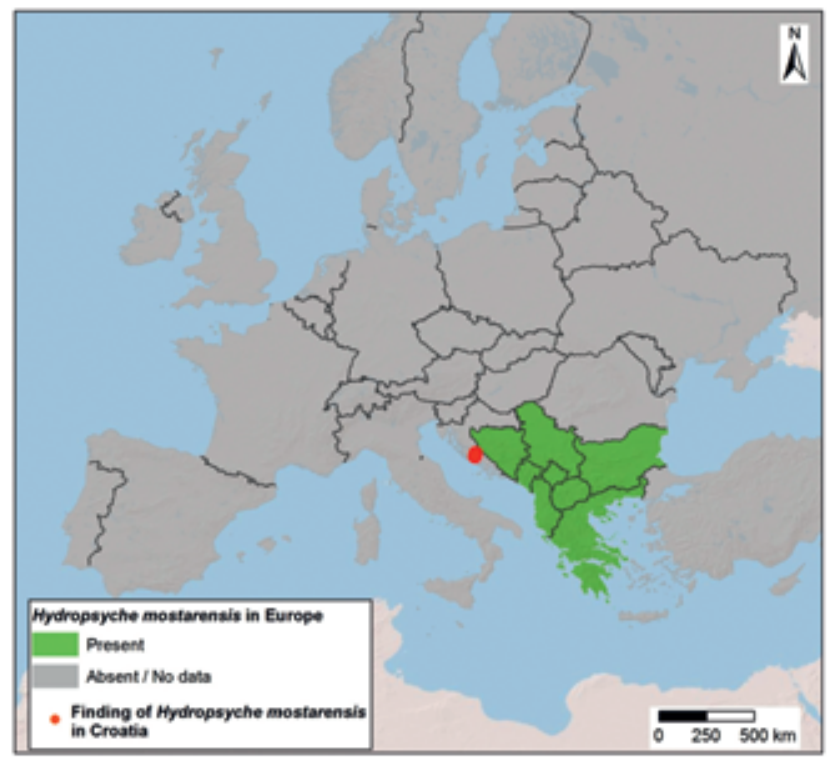

Fig. 6. Distribution of Hydropsyche mostarensis (Klapálek, 1898) in Europe according to Fauna Europaea. Red circle: record in the Krka NP.

Tinodes pallidulus is the fourth species recorded for the first time in the Krka NP during this this study. This species is fourth from the genus Tinodes recorded in the NP and along with the genera Hydropsyche and Limnephilus it is the most numerous genus in the Krka NP (Kučinić et al., 2011; RidL et al., 2015). Tinodes pallidulus is widely distributed in Europe from Scandinavia and Great Britain in the north, and Greece and France in the south, except Island, Iceland, Apennine Peninsula, Corsica, Sardinia and Sicily (Fauna Europaea, 2019; Hickin, 1967; MaLicky, 2005; ŽIvić et al., 2006). In Croatia this species was recorded in the continental (according to Bertić et al., 2001 - Panonnian-Peripanonian) and Mediterranean parts (KučınIć et al., 2016). DNA barcoding proved to be a useful method in identification of T. pallidulus females sampled in the NP.

DNA barcoding of caddisfly fauna in the Krka NP revealed some taxonomically interesting results. Species Oecetis notata (Tab. 1) is recorded in the lower reach of Krka River as a very common species, especially at the locality Skradinski 
Buk (RIDL et al., 2015). In our recent studies, we have additionally found one specimen of O. notata at Roški slap, but also in other rivers in Croatia: Mrežnica River, Gacka River, Dobra River and Cetina River. Besides this specimen from the Roški slap, we have also DNA barcoded two specimens from Gacka River and Dobra River (Ćukušıć, 2019). The sequences obtained from specimens collected in rivers Krka, Dobra and Gacka were submitted to the BOLD Identification Engine which showed a match of 99.84\% (Gacka River), 100\% (Dobra River) and 94.2\% (Krka River) (Tab. 1). Latter result from Krka River clearly indicates intraspecific variability within caddisflies (variability of $8 \%$ ), with the possibility that the specimens from Krka River represent a subspecies (Ćukušić, 2019). Nonetheless, future studies with comprehensive morphological and molecular analyses with inclusion of nuclear genes are required.

Tab. 1. List of species used in this study: first column - identification according to morphological features, last column - DNA species identification with similarity percentage to existing DNA sequences in BOLD database (identification according to the BOLD Identification Engine).

\begin{tabular}{|c|c|c|c|c|}
\hline Species & $\begin{array}{l}\text { Specimen } \\
\text { ID }\end{array}$ & Locality & $\begin{array}{c}\text { BOLD } \\
\text { Sequence ID }\end{array}$ & Species identification (\%) \\
\hline \multicolumn{5}{|l|}{ Family Hydroptilidae } \\
\hline Hydroptila forcipata & THFOR_5 & Roški slap & CROTR-131-19 & Hydroptila forcipata $(100 \%)$ \\
\hline Hydroptila cf. simulans & THSIM_1 & Roški slap & CROTR129-19 & Hydroptila simulans $(99.53 \%)$ \\
\hline Hydroptila sparsa & THSPA_4 & Roški slap & CROTR156-19 & Hydroptila sparsa (99.52) \\
\hline Hydroptilidae & THYD_10 & $\begin{array}{c}\text { Visoavac Lake, right } \\
\text { bank near island } \\
\text { Visovac }\end{array}$ & CROTR224-19 & Orthotrichia costalis $(100 \%)$ \\
\hline Hydroptila sparsa & THSPA_5 & Roški slap & CROTR184-19 & Orthotrichia costalis $(100 \%)$ \\
\hline Hydroptilidae & THYD_11 & $\begin{array}{c}\text { Visovac Lake, right } \\
\text { bank near island } \\
\text { Visovac } \\
\end{array}$ & CROTR184-19 & Orthotrichia costalis $(99.84 \%)$ \\
\hline \multicolumn{5}{|c|}{ Family Polycentropodida } \\
\hline $\begin{array}{l}\text { Cyrnus trimaculatus } \\
\text { (Curtis, 1834) }\end{array}$ & TCTRI_5 & $\begin{array}{l}\text { Visovac Lake, right } \\
\text { bank near island } \\
\text { Visovac }\end{array}$ & CROTR161-19 & Cyrnus trimaculatus (99.68\%) \\
\hline \multicolumn{5}{|l|}{ Family Ecnomidae } \\
\hline $\begin{array}{l}\text { Ecnomus tenellus } \\
\text { (Rambur, 1842) }\end{array}$ & TETEN_5 & $\begin{array}{l}\text { Visovac Lake, right } \\
\text { bank near island } \\
\text { Visovac }\end{array}$ & CROTR234-19 & Ecnomus tenellus (99.69\%) \\
\hline
\end{tabular}




\begin{tabular}{|c|c|c|c|c|}
\hline Species & $\begin{array}{l}\text { Specimen } \\
\text { ID }\end{array}$ & Locality/Family & $\begin{array}{c}\text { BOLD } \\
\text { Sequence ID }\end{array}$ & Species identification (\%) \\
\hline \multicolumn{5}{|l|}{ Family Psychomyiidae } \\
\hline $\begin{array}{l}\text { Tinodes braueri } \\
\text { McLachlan, } 1878\end{array}$ & TTBRA_2 & Roški slap & $\begin{array}{l}\text { CROTR125-19 } \\
\text { CROTR125-19 }\end{array}$ & Tinodes braueri (99.84) \\
\hline $\begin{array}{l}\text { Tinodes waeneri } \\
\text { (Linnaeus, 1758) }\end{array}$ & TTWAE_3 & $\begin{array}{c}\text { Visovac Lake, right } \\
\text { bank near island } \\
\text { Visovac }\end{array}$ & CROTR034-19 & Tinodes waeneri $(98.71 \%)$ \\
\hline Tinodes waeneri & TTWAE-4 & $\begin{array}{c}\text { Visovac Lake, right } \\
\text { bank near island } \\
\text { Visovac }\end{array}$ & CROTR159-19 & Tinodes waeneri $(98.71 \%)$ \\
\hline Tinodes sp. & TRIC_5 & HPP Miljacka & CROTR158-19 & Tinodes pallidulus (99.52\%) \\
\hline \multicolumn{5}{|c|}{ Family Hydropsychidae } \\
\hline Hydropsyche instabilis & THINS_10 & Brljan Lake & CROTR242-19 & Hydropsyche inatabils $100 \%$ \\
\hline $\begin{array}{l}\text { Hydropsyche } \\
\text { mostarensis }\end{array}$ & THMOS_1 & HPP Miljacka & CROTR086-19 & $\begin{array}{c}\text { Hydropsyche mostarensis } \\
(99.34 \%)\end{array}$ \\
\hline \multicolumn{5}{|c|}{ Family Lepidostomatidae } \\
\hline $\begin{array}{l}\text { Lepidostoma hirtum } \\
\text { (Fabricius, 1775) }\end{array}$ & TLHIT_4 & HPP Miljacka & CROTR235-19 & $\begin{array}{l}\text { Lpeidostoma hirtum } \\
\quad(99.29 \%)\end{array}$ \\
\hline Lepidostoma hirtum & TLHIT_3 & Roški slap & CROTR132-19 & Lepidostoma hirtum (100\%) \\
\hline \multicolumn{5}{|l|}{ Family Limnephilidaee } \\
\hline $\begin{array}{l}\text { Limnephilus } \\
\text { marmoratus }\end{array}$ & TLMAR_1 & $\begin{array}{l}\text { Visovac Lake, } \\
\text { right bank near } \\
\text { island Visovac }\end{array}$ & CROTR096-19 & $\begin{array}{l}\text { Limnephilus marmoratus } \\
(99.84 \%)\end{array}$ \\
\hline $\begin{array}{c}\text { Limnephilus } \\
\text { marmoratus Curtis, } \\
1834\end{array}$ & TLMAR_2 & $\begin{array}{l}\text { Visovac Lake, } \\
\text { right bank near } \\
\text { island Visovac }\end{array}$ & CROTR097-19 & $\begin{array}{l}\text { Limnephilus marmoratus } \\
(99.84 \%)\end{array}$ \\
\hline \multicolumn{5}{|l|}{ Family Leptoceridae } \\
\hline Athripsodes albifrons & TAALB_2 & Roški slap & CROTR123-19 & $\begin{array}{c}\text { Athripsodes albifrons } \\
(99.22 \%)\end{array}$ \\
\hline $\begin{array}{l}\text { Ceraclea dissimilis } \\
\text { (Stephens, 1836) }\end{array}$ & TCDIS_3 & Lake Brljan & CROTR254-19 & $\begin{array}{c}\text { Ceraclea dissimiliss } \\
(99.69 \%)\end{array}$ \\
\hline Oecetis cf. notata & TONOT_5 & Roški slap & CROTR130-19 & Oecetis notata $(\mathbf{9 4 . 2} \%)$ \\
\hline
\end{tabular}

\section{CONCLUSIONS}

It this study DNA barcoding method has proved to be a very good and useful method in identification of very small and morphologically similar species from the family Hydroptilidae, as well as female specimens from family Psychomyiidae. We collected 21 specimens for DNA barcoding from four localities in the Krka $\mathrm{NP}$, and identified 16 species among them. All specimens are entered into the BOLD base. Four species are new for the caddisfly fauna of the Krka NP and two species are new for the fauna of Croatia. From taxonomic standpoint the most interesting species found in the NP is Oecetis notata Rambur. DNA barcoding analyses revealed high molecular divergence of specimens collected in the Krka 
NP compared to the specimens collected at other sites, River Gacka and River Dobra.

Future studies on Trichoptera in the Krka NP will be focused on further sampling and DNA barcoding with aim to contribute to detailed knowledge on distribution and biodiversity of caddisflies.

\section{ACKNOWLEDGMENTS}

We are very grateful to the Department of Forest Protection and Wildlife Management) at the Faculty of Forestry, University of Zagreb, two anonymous referees for their useful suggestions and also to Graham McMaster for his assistance with the English language This research is a part of scientific project "DNA barcoding of Croatian faunal biodiversity" (IP-06-2016-9988) funded by the Croatian Science Foundation.

Received December 1, 2019

\section{REFERENCES}

Barnard, P. \& Ross, E., 2012: The Adult Trichoptera (Caddisflies) of Britain and Ireland. RES Handbook Volume 1, Part 17.

Bertić, I., Lampek Pavčnik, I. \& Radovinović, R., 2001: Republika Hrvatska-Prirodna obilježja, stanovništvo i geografske regije (In: Satelitski Atlas Hrvatske). Naknada Ljevak \& GisData, pp 336.

BilandžIJa, H., Morton, B., Podnar M. \& ĆetKović, H., 2013: Evolutionary history of relict Congeria (Bivalvia: Dreissenidae): unearthing the subterranean biodiversity of the Dinaric Karst. Frontiers in Zoology 10, 5. http://www.frontiersinzoology.com/content/10/1/5

Bonacci, O. \& Roje-Bonacci, T., 2015: Analiza hidroloških značajki duž toka rijeke Zrmanje. Vodoprivreda 47, 276-278.

Brehm, G., Murillo-Ramos L., Sihvonen, P., Hausmann, A., Schmidt, C.B., 5, Őunap, E., Moser, A., Mörtter, R., Bolt, D., Bodner, F., Lindt, A., Parra L.E. \& Wahlberg, N., 2019: New World geometrid moths (Lepidoptera: Geometridae): Molecular phylogeny, biogeography, taxonomic updates and description of 11 new tribes. Arthropod Systematic and Phylogeny 77 (3), 457-486. DOI: 10.26049/ASP77-3-2019-5

Cárdenasi, P., Tore Rapp, H., Klitgaard, A.B., Best, M., Thollesson, M. \& Secher Tendal, O., 2013: Taxonomy, biogeography and DNA barcodes of Geodia species (Porifera, Demospongiae, Tetractinellida) in theAtlantic boreo-arctic region. Zoological Journal of the Linnean Society 169, 251-311.

Ćukušrć, A., 2019: Određivanje bioraznolikosti faune tulara (Insecta, Trichoptera) u Hrvatskoj metodom barkodiranja DNA. Doktorski rad, Sveučilište u Zagrebu, pp. 310.

Elías-Gutiérrez, M., Jerónimo, F.M., Ivanova, N.V., Valdez-Moreno, M. \& Hebert, P.D.N., 2008: DNA barcodes for Cladocera and Copepoda from Mexico and Guatemala, highlights and new discoveries. Zootaxa 1839, 1-42.

Fauna Europaea, 2019: https//fauna-eu.org (accessed November, 2019).

FLINT, O.S. Jr., 1992: Studies of Neotropical caddisflies, XXXVIII: a review of the classification and biology of the Neotropical microcaddisflies, with the description of a new genus (Trichoptera: Hydroptilidae: Leucotrichiini). In: Quintero, D. \& Aiello, A. (Eds.) Insects of Panama and Mesoamerica: Selected Studies. Oxford University Press, Oxford, pp. 525-531.

Guo, H.F., Bei Guan, B., Shi, F.M. \& Zhou, Z.J., 2016: DNA Barcoding of genus Hexacentrus in China reveals cryptic diversity within Hexacentrus japonicus (Orthoptera, Tettigoniidae) Zookeys 596, $53-63$.

HALl, T.A., 1999: BioEdit. A user-friendly biological sequence alignment editor and analysis program for Windows 95/98/NT. Nucl. Acids Symp. Ser. 41, 95-98.

Hebert, P.D.N., Cywinska, A., Ball, S.L. \& DeWaArd, J.R. 2003a: Biological identifications through DNA barcodes. Proc. R. Soc. Lond. B. Biol. Sci. 270, 313-322. 
Hebert, P.D.N., Ratnasingham, S. \& DeWaArd, J.R., 2003b: Barcoding animal life: Cytochrome c oxidase subunit 1 divergences among closely related species. Proc R Soc Lond B Biol Sci 270, S596-S599.

Hickin, N.E., 1967: Caddis Larvae, Larvae of the British Trichoptera. Hutchinson of London, 476 pp., London.

Holzenthal, R.W., Blahnik, R.J., Prather, A.L. \& KJer, K.M., 2007: Order Trichoptera Kirby, 1813 (Insecta), Caddisflies. Zootaxa 1668, 639-698.

Ibrahimi, H., Kučinić, M., Gashi, A. \& Grapci-Kotori, L., 2012: The caddisfly fauna (Insecta, Trichoptera) of the rivers of the Black Sea basin in Kosovo with distributional data for some rare species. Zookeys 182, 71-85. doi: 10.3897/zookeys.182.2485

KANG, Y., DeNG, Z., ZANG R. \& LoNG, W., 2017: DNA barcoding analysis and phylogenetic relationships of tree species in tropical cloud forests. Scientific Reports 7, 12564 DOI:10.1038/s41598-017-13057-0 9

Karaouzas, I., 2018: The larvae of three Greek species of Hydropsyche (Trichoptera: Hydropsychidae) and key for larvae of known Aegean Hydropsyche species. Zootaxa 4382 (2), $381-392$ doi. org/10.11646/zootaxa.4382.2.9

Kučinić, M., VučKović, I., KutnjaK, H., Šerić Jelaska, L. \& Marguš, D., 2011: Diversity, distribution, ecology and biogeography of caddisflies (Insecta: Trichoptera) in the Krka river (National Park „Krka“, Croatia). Zoosymposia 5, 255-268.

Kučinić, M., Ćukušić, A., Podnar, M., Landeka, M., Plavec, H., Plantak, M., Акimbekova, N., \& ŽAlAC, S., 2016: The first record of Tinodes antonioi Botosaneanu \& Taticchi-Viganò, 1974 (Insecta, Trichoptera) in Croatia with DNA barcoding and ecologfical dana and notice of biodiversity and distribution oft he genus Tinodes in Croatia. Natura Croatica 25 (1), 131-149.

Kumanski, K.P., 1985: Trichoptera, Annulipalpia. Fauna Bulgarica 19, 1-244.

Kumanski, K.P., 1988: Trichoptera, Integripalpia. Fauna Bulgarica 19, 1-354.

Linnaeus, C., 1758: Systema naturae per regna tria naturae: secundum, classes, ordines, genera, species, cum characteribus, differentiis, synonymis, locis (in Latin). Stockholm: Laurentius Salviu

Malicky, H., 2004: Atlas of European Trichoptera. Springer, Dordrecht, pp. 384.

Malicky, H., 2005: Die Köcherfliegen Griechenlands. Denisia 17, 1-240.

Marshall, J.E., 1978: Trichoptera, Hydroptilidae. Handbooks for the Identification of British Insects Vol. I, Part 14 (a) (Ed. WATson, A.). Royal Entomological Society of London, pp. 31, London.

Martynov, A.V., 1913: Contribution to the knowledge of the Trichopterous fauna of the Caucasus [in Russian]. Arb. Zool. Labor. Warschau [Trav. labr. Zool. Univ. Warsaw], 1912, 1-111.

Morse, J.C. (ed.), 2019: Trichoptera World Checklist. http://entweb.clemson.edu/database/trichopt/ index.htm [acess 4 December 2019.]

O'Connor, J.P., 2015: A Catalogue and Atlas of the Caddisflies (Trichoptera) of Ireland. Occasional Publication of the Irish Biogeographical Society, No. 11.

Previšić, A., Graf, W., Vitecek , S., Kučinić M., Báliant M., Keresztes L., Pauls S.U. \& J. Waringer, J., 2014: Cryptic diversity of caddisflies in the Balkans: the curious case of Ecclisopteryx species (Trichoptera: Limnephilidae). Arthropod Systematics \& Phylogeny 72 (3), 309-329.

Ratnasingham, S. \& Hebert, P.D.N., 2007: BOLD - The Barcode of Life Data System (www. barcodinglife.org). Mol. Ecol. Notes 7, 355-364. doi:10.1111/j.1471-198286.2006.01678.x

Ridl, A., Previšić, A., Ivković, M. \& Mihaljević, Z., 2015: Emergencija tulara (Trichoptera, Insecta) sedrenih barijera u NP “Krka”. Zbornik radova o NP Krka (ed. Marguš, D.), 183-194.

Santos, A.P.M., Nessimian, J.L. \& TAKiYA, D.M., 2016: Revised classification and evolution of leucotrichiine microcaddisflies (Trichoptera: Hydroptilidae) based on morphological and molecular. Systematic Entomology 41, 458-480. DOI: 10.1111/syen.12168

Smit, J., Raemakers, I. \& Beentjes, K., 2018: First host record of Myopa pellucida Robineau-Desvoidy (Diptera: Conopidae) identified using DNA barcoding. Zootaxa 4521 (4), 593-596

Stanić-Koštroman, S., Kučinić, M., Kolobara, A., Škobić, D., Knezović, L. \& Durbešić, P., 2012 : Light-trapped caddisflies (Insecta: Trichoptera) as indicators of the ecological integrity of the Lištica River, Bosnia and Herzegovina. Entomologica Croatica 16 (1-4), 21-36.

Stanić-Koštroman, S., Previšić, A., Planinić, A., Kučinić, M., ŠKobić, D., Dedić, A. \& Durbešić, P., 2015: Environmental determinants of contrasting caddisfly (Insecta, Trichoptera) biodiversity in the Neretva and Bosna River basins (Bosnia and Herzegovina) under temperate and Mediterranean climates. International Review of Hydrobiology 100 (2), 79-95. 
Stephens, J.F., 1836: Illustrations of British Entomology; or a Synopsis of Indigenous Insects: Containing their Generic and Specific Distinctions; with an Account of their Metamorphoses, Times of Appearance, Localities, Food, and Economy, as far as Practicable. Mandibulata. Vol. VI. [Trichoptera, pages 146-208]. Baldwin and Cradock, London, pp. 240.

Tyagi, K., Kumar, V., Singha, D., Chandra, K., Laskar, B.A., Kundu, S., Chakraborty R. \& Chatterjee, S. A., 2017: Barcoding studies on Thrips in India: Cryptic species and Species complexes. Scientific Reports 4898, DOI:10.1038/s41598-017-05112-7

Vaglia, T., Haxaire, J., Kitching, I.J., Meusnier, I. \& Rougerie, R., 2008: \& Morphology and DNA barcoding reveal three cryptic species within the Xylophanes neoptolemus and loelia species-groups (Lepidoptera: Sphingidae). Zootaxa 1923, 18-36.

Vitecek, S., Previšić, A., Kučinić, M., Báliant, M., Keresztes, L., Waringer, J., Paulus, S.U., Malicky, H. \& Graf, W., 2015: Description of a new species of Wormaldia from Sardinia and a new Drusus species from the western Balkans (Trichoptera, Philopotamidae, Limnephilidae). Zookeys 496, 85-103.

Vitecek, S., Kučinić, M., Previšić, A., Živić, I., Stojanović, K., Keresztes, L., Báliant, M., Hoppeler, F., Waringer, J., Graf, W. \& Pauls, U. S., 2017: Integrative taxonomy by molecular species delimitation : multi-locus data corroborate a new species of Balkan Drusinae microendemics. BMC Evolutionary Biology 17, 129-1-129-18.

WARINGER, J. \& GRAF, W., 2011: Atlas der mitteleuropäischen Köcherfliegenlarven - Atlas of Central European Trichoptera Larvae. Erik Mauch Verlag, Dinkelscherben, pp. 469.

Žıvić, I., Marković, Z. \& Brajković, M., 2006: Contribution to the faunistical list of Trichoptera (Insecta) of Serbia. Acta Emtomologica Slovenica 14 (1), 55-88. 